\title{
Development and Quality Evaluation of Galactogogue Product Enriched with Garden Cress for Lactating Women
}

\author{
Sumiran Patel and Samit Dutta*
}

Department of Food Business Management, College of Food Processing Technology and Bioenergy, Anand Agricultural University, Anand-388110, Gujarat, India

*Corresponding author

\begin{tabular}{l} 
K e y w o r d s \\
$\begin{array}{l}\text { Garden cress, Wheat, } \\
\text { Finger millet, } \\
\text { Germination, Anti- } \\
\text { nutrients, Antioxidants, } \\
\text { Calcium content, Iron } \\
\text { content, Lactating women }\end{array}$ \\
Article Info \\
$\begin{array}{l}\text { Accepted: } \\
15 \text { October } 2018 \\
\text { Available Online: } \\
10 \text { November } 2018\end{array}$ \\
\hline
\end{tabular}

\section{Introduction}

Pregnancy and lactation periods are the most nutritionally demanding times of a woman's life. The body needs enough nutrients every day to support the growth of the baby and the maintenance of the mother's body (Foster, 2009). Inadequate nutrition during lactation is reflected on both the quality and quantity of milk secreted. Galactogogues are foods that help to produce more milk. Lactating mothers
The present investigation entitled "Development and Quality evaluation of galactogue product for lactating women enriched with Garden cress" was conducted with an idea to prepare and standardize the process of making nutri-cereals based product. Th3e objectives of the study were to formulate the multi nutrient laddoo for lactating women and to standardize the final food product for nutritional and quality parameters. To cater the elevated demand of nutrition, garden cress and finger millet were selected as major ingredients, being richer sources of calcium and iron. For better nutritional quality, digestibility and organoleptic property, wheat was also selected as major ingredient. The processing steps like soaking and germination helped to lower anti-nutritional factors and better retention of antioxidants. Response surface methodology (RSM) based on Central Composite Rotatable Design (CCRD) at five different levels was adopted for three variables viz. garden cress, wheat and finger millet, to optimize the formulation for multi nutrient laddoo. Optimized product was prepared by mixing germinated and roasted garden cress $(5.76 \mathrm{~g})$, wheat $(82.51 \mathrm{~g})$ and finger millet $(21.52 \mathrm{~g})$ flours with ghee (30 per cent) and sugar (40 per cent) of the total weight of the flour. The moisture, protein, fat, ash, crude fibre and carbohydrates on dry matter basis for final product were 12.06, 14.84, $31.51,3.04,3.02$ and 35.53 per cent respectively. The final product was having 144.65, 4.28 and $241 \mathrm{mg} / 100 \mathrm{~g}$ of calcium, iron and phosphorus respectively.

are given special preparations during this time which supply iron, protein, calcium and Bcomplex vitamins (Ramadas et al., 2011).

Garden cress has been considered as an important nutritional and medicinal plant in India since the Vedic era (between 500- 1700 B.C.).Garden cress has significant amounts of iron, calcium, folic acid, and vitamins A, E, and C. Garden cress seeds are loaded with not just protein, but also linoleic and arachidonic 
fatty acids. Cress is said to help regulate the menstrual cycle, and cress seeds help increase milk production and secretion in lactating mothers. Because of its high iron and protein content, it is good for post-partum and lactating mothers. Cress is also recommended in the treatment of iron-deficiency anemia due to its iron content (Kasabe et al., 2012). The seeds of the plant are rubefacient, galactogogue, emmengogue, laxative, tonic, aphrodisiac and diuretic. Health drink and food products incorporated with garden cress seeds or its fractions were sensorily acceptable. Garden cress seed can be used as a promising multipurpose medicinal source (Doke and Guha, 2014).

Wheat is the most staple food crop for more than one third of the world population and contributes more calories and proteins to the world diet than any other cereal crops. Wheat is considered as a good source of proteins, minerals, B-group vitamins and dietary fibre although the environmental conditions can effect nutritional composition of wheat grains with its essential coating of bran, vitamins and minerals; it is an excellent health-building food. Wheat is also a good source of traces minerals like selenium and magnesium, nutrients which are essential to good health. Because of its good amount of calories and protein, it is an essential cereal for lactating women (Kumar et al., 2011).

Finger millet is rich in protein, iron, phosphorus, calcium, fibre and vitamin content. The calcium content is higher than all the cereals and iodine content said to be highest among all the food grains. It is an important cereal because of its excellent storage properties of the grains and the nutritive value, which is higher than that of rice and equal to that of wheat. Due to the presence of anti-nutrients in grains such as tannins and phytates, these micronutrients are less bioaccessable. These anti-nutritional factors modify the nutritional value of the individual grains. Calcium deficiency leading to bone and teeth disorder, iron deficiency leading to anaemia can be overcome by introducing finger millet in daily diet (Singh and Singh, 2012).

Anti-nutritional factors are substances which reduce the nutritive value of foods by inhibiting digestibility and utilization of proteins. The nutritional value of pulses may be adversely affected by the presence of antiphysiological or toxic substances such as trypsin inhibitors, phytates, lectins, polyphenols, cyanogenic compounds, saponins and anti-vitamins (Jain et al., 2009).

Antioxidants are naturally occurring plant substances that protect the body from damaged caused by harmful molecules called free radicals. Antioxidants help prevent oxidation which can cause damage to cells and may contribute to aging. They may improve immune function and perhaps lower the risk for infection, cardiovascular disease, and cancer. Antioxidants exist as vitamins, minerals and other compounds in foods. A diet containing plenty of fruits and vegetables, whole grains and nuts can supply all the antioxidants your body needs. Diet rich in antioxidants can be very beneficial (Pervical, 1998).

\section{Materials and Methods}

This experiment was carried out in The College of Food Processing Technology and Bio-energy, Anand Agricultural University, Anand, Gujarat.

For the requirement of the experiment, Garden cress seeds were procured from Medicinal and Aromatic Plant Research Station, Anand Agricultural University, Anand, Gujarat. For the formulation of the galactogogue product, Wheat and Finger 
millet grains were procured from the Gunj market, Anand, Gujarat. Amul pure ghee and ground sugar were also procured from the local market.

For better retention of the nutrients and to reduce anti-nutrients, several pre-treatment were given i.e. soaking, germination, drying and roasting to the raw materials which are described here. The garden cress seeds were soaked for $12 \mathrm{~h}$ (Mukhopadhyay et al., 2010), wheat grains were soaked for $10 \mathrm{~h}$ (Hussain et al., 2011) and finger millet grains were soaked for $12 \mathrm{~h}$ (Khokhar and Chauhan, 1986) at room temperature. The soaked grains were stirred periodically in order to remove the gases accumulated around the seeds and the steep water was changed after every $4 \mathrm{~h}$ of interval.

The garden cress seeds were allowed to germinate for 8,12 , and $15 \mathrm{~h}$ at 15,25 and 35 ${ }^{\circ} \mathrm{C}$ temperature. The wheat grains were allowed to germinate for 36,48 and $72 \mathrm{~h}$ at 30, 34 and $37{ }^{\circ} \mathrm{C}$ temperature. The finger millet grains were allowed to germinate for 12, 24 and $36 \mathrm{~h}$ at 30,34 and $37{ }^{\circ} \mathrm{C}$ temperature. The grains were removed and washed after every $12 \mathrm{~h}$ interval in order to prevent development of off smell. The germinated seeds/grains then dried under vacuum tray dryer by layering them uniformly at $700 \mathrm{~mm}$ of $\mathrm{Hg}$ vacuum.

For optimization of levels of garden cress, wheat and finger millet in nutri-cereals based formulation, a three factor (five levels of each) second order central composite rotatable experimental design was adopted.

The independent factors were the Garden cress, Wheat and Finger millet in product formulation. The responses were the organoleptic attributes (Colour, Flavour, Texture, Taste and Overall acceptability), Iron and Calcium content.

\section{Chemical analysis}

Moisture: Estimation of moisture by hot air oven method $105^{\circ} \mathrm{C}$ for hrs (AOAC, 1995).

Fat: Extracting the sample in a Soxhlet apparatus for 6-8 $\mathrm{hr}$ using petroleum ether. The solvent is evaporated and the residue is weighed (Ranganna, 1986).

Protein: The estimation of nitrogen is done by kjeldahl method were in the protein content is obtained by multiplying the nitrogen value with 6.25 (Ranganna, 1986).

Crude fibre: Fibra-plus instrument was used for estimation of crude fibre content (Ranganna, 1986).

Ash: The samples were placed in temperature controlled furnace at $550{ }^{\circ} \mathrm{C}(\mathrm{AOAC}, 1980)$.

Total sugar: Total sugar estimation was done by Lane and Eynon method (Ranganna, 1977).

Phytic acid: Phytic acid estimation of wheat and finger millets samples was dome by phytic acid kit (Megazyme International Limited, Ireland).

Tannin: Estimation of tannin of wheat was done by vanillin- $\mathrm{HCl}$ method described by Steve (2012).

Total cyanogen: Total cyanogen of garden cress was determined by the method described in AOAC (1986).

Oxalate content: Oxalate in garden cress was determined by AOAC (2005) method.

Trypsin inhibitor activity: Trypsin inhibitor activity in finger millet was determined according to method given by Kakade et al., (1974). 
Total phenolic content: Total phenolics were determined using Folin-Ciocalteu reagent described by Agarwal and Sharma (2013).

Sensory evaluation: After preparing the product, was evaluated for colour, flavour, texture, taste and overall acceptability using nine point hedonic scale (1=dislike extremely to $9=$ like extremely) by a panel of 8 judges comprising professor and research associates of the College of Food Processing Technology and Bio-energy, Anand Agricultural University, Anand, Gujarat.

Statistical analysis: The results obtained during the experimentation, were subjected to one way ANOVA and Standard deviation using Microsoft Excel 2010.

For optimization of the product formulation (levels of garden cress, wheat and finger millet) the CCRD analysis was carried out using Design Expert, 7.0.0 software.

\section{Results and Discussion}

\section{Proximate composition of raw seeds/grains}

The moisture content in garden cress, wheat and finger millet was $10.06,10.80$ and 12.25 per cent respectively. The protein, fat, crude fiber and ash content in garden cress were $16.20,2.40, \quad 3.40$ and 1.30 per cent respectively.

The composition of garden cress was found to be in accordance with composition of garden cress reported by Sarkar et al., (2014).

The protein, fat, crude fiber and ash content in wheat grain were $12.40,2.30 .2 .10$ and 1.90 per cent respectively whereas in finger millet, the protein, fat, crude fiber and ash content were $9.14,1.35,3.03$ and 2.42 per cent respectively. The composition of wheat was found to be similar to, as reported by Kumar et al., (2011) whereas the composition of finger millet was found to be similar to, as reported by Singh and Singh (2012).

\section{Effect of processing treatments on garden cress}

The total cyanogen in raw garden cress was $6.83 \mathrm{mg} / 100 \mathrm{~g}$ which was decreased upto 5.23 $\mathrm{mg} / 100 \mathrm{~g}$ after $12 \mathrm{~h}$ of soaking and it was further decreased upto $3.63 \mathrm{mg} / 100 \mathrm{~g}$ after 16 $\mathrm{h}$ of germination at $25^{\circ} \mathrm{C}$. Oxalic acid content was reduced from $118.43 \mathrm{mg} / 100 \mathrm{~g}$ to 96.15 $\mathrm{mg} / 100 \mathrm{~g}$ during the $12 \mathrm{~h}$ soaking. Germination of soaked garden cress also reduced the oxalic acid content. Oxalic acid reduced from $118.43 \mathrm{mg} / 100 \mathrm{~g}$ to 53.85 $\mathrm{mg} / 100 \mathrm{~g}$ by giving germination treatment for 8,12 and $16 \mathrm{~h}$ at different temperature of 15 , 25 and $35{ }^{\circ} \mathrm{C}$. The maximum reduction in oxalic acid levels was found to be 44.64 per cent at $16 \mathrm{~h}$ of germination at $25^{\circ} \mathrm{C}$. Total phenolic content was increased from 14.67 $\mathrm{mg}$ GAE/100 $\mathrm{g}$ to $27.82 \mathrm{mg}$ GAE/100 $\mathrm{g}$ during the $12 \mathrm{~h}$ soaking. Germination of soaked garden cress also increased the total phenolic content. The total phenolic content increased from $14.67 \mathrm{mg}$ GAE/ $100 \mathrm{~g}$ to $50.80 \mathrm{mg} \mathrm{GAE} / 100 \mathrm{~g}$ by giving germination treatment for 8,12 and $16 \mathrm{~h}$ at different temperature of 15,25 and $35^{\circ} \mathrm{C}$.

\section{Effect of processing treatments on wheat}

Phytic acid was decreased from $744 \mathrm{mg} / 100 \mathrm{~g}$ to $657.3 \mathrm{mg} / 100 \mathrm{~g}$ during $10 \mathrm{~h}$ soaking. It was found that total 51.17 per cent reduction in phytic acid content after giving the $10 \mathrm{~h}$ soaking treatment and germination for $72 \mathrm{~h}$ at $37{ }^{\circ} \mathrm{C}$ which was $381.32 \mathrm{mg} / 100 \mathrm{~g}$. Tannin content was decreased from $602.3 \mathrm{mg} / 100 \mathrm{~g}$ to $486.07 \mathrm{mg} / 100 \mathrm{~g}$ during $10 \mathrm{~h}$ soaking. It was found that total 49.19 per cent reduction in tannin content after giving the $10 \mathrm{~h}$ soaking treatment and germination for $72 \mathrm{~h}$ at $37{ }^{\circ} \mathrm{C}$ which was $296.30 \mathrm{mg} / 100 \mathrm{~g}$. 
Effect of processing treatments on finger millet

Phytic acid was decreased from 676.77 $\mathrm{mg} / 100 \mathrm{~g}$ to $238.49 \mathrm{mg} / 100 \mathrm{~g}$ during $12 \mathrm{~h}$ soaking followed by germination for $36 \mathrm{~h}$ at $37{ }^{\circ} \mathrm{C}$ which corresponds to a total 55.24 per cent reduction in phytic acid content. During the soaking, trypsin units were reduced from $6.37 \mathrm{TUI} / \mathrm{mg}$ to $5.70 \mathrm{TUI} / \mathrm{mg}$ which were further reduced to $1.91 \mathrm{TUI} / \mathrm{mg}$ after $36 \mathrm{~h}$ of germination at $37^{\circ} \mathrm{C}$.

Optimization of germination period for garden cress, wheat and finger millet

For optimization of best temperature and time period for germination of garden cress, the factors considered were increase in total phenolic content, decrease in oxalates and decrease in total cyanogen. The total phenolic content was found maximum at $25^{\circ} \mathrm{C}$ for $16 \mathrm{~h}$ germination period and at the same germination period, there was maximum reduction in total cyanogen as well as oxalic acid. At optimized germination period, there was 34.6 per cent increase in total phenolic content, 48 per cent decrease in total cyanogen and 46 per cent decrease in oxalic acid. For optimization for best temperature and time period of germination for wheat, the factors considered were decrease in phytic acid content and decrease in tannin. The optimized germination condition selected for wheat was $72 \mathrm{~h}$ of germination at $37{ }^{\circ} \mathrm{C}$ temperature and 85 per cent relative humidity. At optimized germination period, there was 51.25 per cent decrease in phytic acid content and 49.20 per cent decrease in tannin content.

For optimization for best temperature and time period of germination for finger millet, the factors considered were decrease in phytic acid content and decrease in trypsin inhibitor activity. The optimum germination period selected was $36 \mathrm{~h}$ of germination at $37{ }^{\circ} \mathrm{C}$. At optimized germination period, there was 35.30 per cent decrease in phytic acid level and 28.98 per cent decrease in trypsin inhibitor activity.

Development of
product using
methodology

The experiments for optimization of nutricereals based laddoo from garden cress flour, wheat flour and finger millet flour were conducted as per the CCRD experimental design. The sensory score based on 9-point hedonic scale, calcium and iron content were taken as responses against the CCRD experiments and there were 20 trials suggested by the design.

The best solution was found with the desirability value of 1.00 . The predicted values of color 7.34, flavor 7.43, texture 7.21, taste 7.36, overall acceptability of 7.38, calcium content of $118.49 \mathrm{mg}$ and iron content of $3.93 \mathrm{mg}$ which were obtained by combination of garden cress as $5.76 \mathrm{~g}$, wheat as $82.51 \mathrm{~g}$ and finger millet as $21.52 \mathrm{~g}$ for the optimized nutri-cereals based laddoo. The actual values of flours optimized were $5 \mathrm{~g}$ garden cress, $80 \mathrm{~g}$ wheat and $30 \mathrm{~g}$ finger millet.

\section{Profiling of nutri-cereals based laddoo}

The final nutri-cereals based laddoo was prepared using optimized parameters. The product, so prepared was tested for chemical properties, mineral profiling and microbiological studies.

\section{Compositional analysis of nutri-cereals based laddoo}

The moisture, protein, fat, ash, crude fibre and carbohydrates of the nutri-cereals based laddoo were 12.06, 14.84, 31.51, 3.04, 3.02 
and 35.53 per cent respectively, whereas the total sugar was 39.28 per cent.

Mineral analysis of nutri-cereals based laddoo

The mineral composition of the product for calcium, iron and phosphorus was analysed and they were $144.65 \mathrm{mg} / 100 \mathrm{~g}, 4.28 \mathrm{mg} / 100$ $\mathrm{g}$ and $241 \mathrm{mg} / 100 \mathrm{~g}$. Thus the developed nutri-cereals based laddoo possessed ample amount of minerals. If four servings of the product are given in a day, a pregnant/lactating woman can get 12-21 per cent iron, 68-71 per cent calcium and 10-12 per cent phosphorus of her daily recommended requirements by ICMR (2009).

\section{Microbiological analysis of nutri-cereals based laddoo}

The standard plate count, coliform and yeast and mold count observed in nuti-cereals based laddoo were 25,000, nil and $36 \mathrm{cfu}$ per g, respectively which was found in the range of khoa which were 50,000, 50 and 50 colonies per g respectively (FSSAI, 2011).

Garden cress is a rich source of iron and calcium. The seeds of the plant are rubefacient, galactogogue, emmengogue, laxative, tonic, aphrodisiac and diuretic. Cereal grains are the single most important source of calories to a majority of the world population. Wheat (Triticum spp.) is the main cereal crop in India. Wheat is considered a good source of protein, minerals, B-group vitamins and dietary fiber and with its essential coating of bran, it is an excellent health-building food. Finger millet is one of the minor cereals, which is known for its several health benefits due to its polyphenol and dietary fibre contents. It is a good source of carbohydrates, fat, calcium and dietary fibre. The presence of certain anti-nutrients like phytates, tannins, oxalates, total cyanogens and trypsin inhibitor may interfere in mineral bioavailability, decrease in protein quality and other nutrients. Certain pretreatments have been reported to reduce the anti-nutrients and there by enhance the nutritional status of garden cress, wheat and finger millet, and render it suitable for food product manufacture.

Supplementary nutrition is must for the normal and healthy growth of a child during pregnancy/lactation. The supplementary or malted foods available in the developing countries like India are costlier and can't be afforded by majority of the people. Moreover the food preparations consumed during lactation, do not contain adequate micronutrients desired for pregnancy/lactation women. Therefore, in order to overcome the problems of maternal malnutrition in developing countries and to cater the need of the lactating women in terms of nutrition, an attempt was made for developing process of nutri-cereals based galactogogue product enriched with garden cress for lactating women. The study was carried out in the two phases. In first phase, the formulation and processing parameters for developing nutricereals based laddoo was optimized and in second phase chemical, nutritional, organoleptic and microbiological characterization of developed nutri-cereals based laddoo was carried out.

The actual values of flours optimized were 5 $\mathrm{g}$ garden cress, $80 \mathrm{~g}$ wheat and $30 \mathrm{~g}$ finger millet. The average colour, flavour, texture, taste and overall acceptability score were $7.75,7.87,8,7.93$ and 8.12 respectively. The calcium and iron content in the final product were $144.65 \mathrm{mg} / 100 \mathrm{~g}$ and $4.28 \mathrm{mg} / 100 \mathrm{~g}$ respectively. The present investigation resulted in the development of a nutri-cereals based galactogoue product with highly acceptable quality attributes. In view of the findings of the present study, it may be concluded that the nutri-cereals based laddoo 
developed under the study showed a nutritional profile which is highly suitable for lactating women. Also in terms of organoleptic quality, the product was found to be highly acceptable. It was observed that microbiological quality of freshly prepared nutri-cereals based laddoo was satisfactory. The nutri-cereals based laddoo thus prepared have opened up a newer opportunity to solve problem of maternal malnutrition. The technology developed is quite simple and low level processing along with cheap raw material made the product suitable for cost effective production industrial production.

\section{References}

Agarwal, N. and Sharma, S. (2013). Garden cress (Lepidium sativum L.) - A nonconventional traditional plant item for food product. Indian Journal of Traditional Knowledge, 12(4): 699-706.

AOAC (1980). Official methods of analysis. Association of Official Analytical Chemists. Washington D. C., USA.

AOAC (1986). Official methods of analysis. Association of Official Analytical Chemists. Washington D. C., USA.

AOAC (1995). Official methods of analysis. Association of Official Analytical Chemists. Washington D. C., USA.

AOAC (2005). Official methods of analysis. Association of Official Analytical Chemists. Washington D. C., USA.

Doke, S. and Guha, M. (2014). Garden cress (Lepidium sativum L.) seed- An important medicinal source: A review. Journal of Natural Product and Plant Resources, 4(1): 69-80.

Foster, J. and Shertzer, J. (2009). Nutritional needs of pregnancy and breastfeeding, $1-4$.

Hussain, I., Uddin, M. and Aziz, M. (2011). Optimization of antinutritional factors from germinated wheat and mungbean by Response Surface Methodology,
International Food Research Journal, 18(3): 957-963.

ICMR (2009). Nutrient requirements and recommended dietary allowances for Indians. Indian Council of Medical Research report, Hyderabad.

Jain, A., Kumar, S. and Panwar, J. (2009). Antinutritional factors and their detoxification in Pulses- A review. Agriculture Review, 30(1):64-70.

Kakade, M. L., Rackis, J. J., Mcghee, J. E. and Puski, G. (1974). Determination of trypsin inhibitor activity of soya products. Cereal Chemistry, 51:376

Kasabe, P., Patil, P., Kamble, D., and Dandge, P. (2012). Nutritional, elemental analysis and antioxident activity of garden cress (Lepidium sativum L.) seeds. International Journal of Pharmacy and Pharmaceutical Sciences, 4(3): 392-395.

Khokhar, S., and Chauhan, B. (1986). Effect of domestic processing and cooking on in-vitro protein digestibility of moth bean. Journal of Food Science, 51(4): 1083

Kumar, P., RK Yadava, Gollen, B., Kumar, S., Verma, R.K. and Yadav, S. (2011). Nutritional Contents and Medicinal Properties of Wheat: A Review. Life Sciences and Medicinal Research, 1-10.

Mukhopadhyay, D., Parihar, S., Chauhan, S., Preeti, and Joshi, S. (2010). Effect of temperature desiccation on seed viability of Lepidium sativum L., New York Science Journal, 3(5): 34.

Pervical, M. (1998). Antioxidants. Clinical Nutrition Insights, Advanced Nutrition Publications, 1-4.

Ramadas, V., Geetha, C. and Begum, K. (2011). Food management and child care, Government of Tamilnadu, 1-293.

Ranganna, S. (1977). Handbook of analysis and quality control for fruits and vegetable products, Tata McGraw-Hill 
Publishing Company Limited, New Delhi, Tata McGraw-Hill publications.

Ranganna, S. (1986). Handbook of analysis and quality control for fruits and vegetable products, Tata McGraw-Hill Publishing Company Limited, New Delhi, Tata McGraw-Hill publications.

Sarkar, S., Datta, S. and Ghosh, I. (2014). Experimental studies on nutritional and medicinal role of garden cress seed on animal and human being- A review.
International Journal of Medicinal Chemistry and Analysis, 4(1): 41-45.

Singh, P. and Singh, R. (2012). Finger millet for food and nutritional security. African Journal of Food Science, 6(4): 77-84.

Steve, I. Oluwole (2012). Influence of germination and fermentation on chemical composition, protein quality and physical properties of wheat flour (Triticum aestivum). Journal of Cereals and Oilseeds, 3(3): 34-47.

\section{How to cite this article:}

Sumiran Patel and Samit Dutta. 2018. Development and Quality Evaluation of Galactogogue Product Enriched with Garden Cress for Lactating Women. Int.J.Curr.Microbiol.App.Sci. 7(11): 1841-1848. doi: https://doi.org/10.20546/ijcmas.2018.711.208 